\title{
The Moderating Role of Sea Service Period on the Relationship between Perceived Organizational Justice and Job Satisfaction: Evidence from Seafarers
}

\author{
Murat YORULMAZ, Gönül KAYA ÖZBAĞ \\ Kocaeli University, Maritime Faculty, Turkey \\ muratyor@gmail.com; ORCID ID: https://orcid.org/0000-0002-5736-9146 \\ gonul.kaya@kocaeli.edu.tr; ORCID ID: https://orcid.org/0000-0002-4205-6171 \\ Corresponding Author: Murat YORULMAZ
}

\begin{abstract}
Although the number of organizational justice studies has increased rapidly in recent years, little research has focused on fairness perceptions of seafarers. Therefore, this paper intended to fill the gap by investigating the effect of organizational justice perceptions of seafarers on their job satisfaction described by three facets including procedural justice, distributive justice and interactional justice. The data obtained through face-to-face survey technique were analyzed using SPSS 22 and AMOS 22 (with PROCESS macro) statistical package programs. The findings generated from regression analysis point that justice perception of seafarers positively affects their job satisfaction level. Furthermore, the length of seafarers' sea service has a moderating role between perceived organizational justice and job satisfaction. The managerial implications of the results are discussed in light of the particular context of the maritime industry with some suggestions for enhancing justice and satisfaction perceptions of seafarers.
\end{abstract}

\section{Keywords}

Organizational Justice, Job Satisfaction, Seafarers.

\section{Introduction}

Determining antecedents of job satisfaction (JS) has been an overriding effort of scholars for years and nowadays many of them have recognized the role of perceived organizational justice (POJ) of employees in designing this desired work attitude. After all, researchers have seemed to agree that organizational justice is a powerful determinative of JS [1][2][3]. However, it is apparent that the linkage between justice and JS is too complex and thus it is beneficial to explore the relationship in different cultural and work settings. Although, how to maintain and promote JS in the workplace is crucial for all professions, to strengthen the feelings of JS among seafarers is even more important

To cite this article: Yorulmaz, M. \& Kaya Özbağ, G. (2020). The Moderating Role of Sea Service Period on the Relationship between Perceived Organizational Justice and Job Satisfaction; Evidence from Seafarers. Journal of ETA Maritime Science, 8(3), 134-149. To link to this article: https://dx.doi.org/10.5505/jems.2020.35693 
due to circumstances specific to life on a ship. Seafarers live an isolated life on board for months away from their families and society which makes seafaring a highly unsatisfied and stressful occupation.

Seafarers suffer from long working hours, shift work and watchkeeping, high job demands and high stress, poor quality sleep, hectic pace, physical work hazards, and ill health [4][5][6][7]. In addition, permanent job-related physical factors on vessels including noise, temperature, vibration, and ship motion decrease seafarers' satisfaction, both during work hours and during leisure time [8][9]. Thus, relative to other areas of employment, disadvantageous working conditions create high turnover rates in the shipping industry which in turn costs the organization time and money [10][11][12]. Many pieces of research have indicated that poor and unfavourable working conditions at sea are negatively influencing both the recruitment of young people into a seafaring career and retaining in-service seafarers [11][12][13] [14][15]. All these mentioned aspects jointly decrease the overall performance and competitiveness of marine organizations.

One possible solution may increase JS of seafarers that may have a significant impact on employee behavioural responses, such as job performance, productivity and efficiency, intention to quit, organizational turnover, absenteeism, work engagement and organizational identification [16][17] [18][19][20][21][22]. In general, JS refers to an employee's subjective perception of his/her work and all aspects of the work environment. It is influenced by many organizational elements, ranging from salaries, job security, job autonomy, career prospects, to the relationship between employees and colleagues. Organizational justice raises above all these potential elements because seafarers who feel that their contributions and sacrifices are not reciprocated by the organisation will be frustrated and most likely to respond negatively.

For that reason, the data of this study are drawn from marine employees in order to analyze the linkage between POJ and JS in the maritime industry which is strategic for the economy of countries. Although the positive effects of POJ on employees' JS have been confirmed, to the best of the authors' knowledge, this connection has not been investigated in the shipping industry. It is vital to determine the predictors of seafarers' satisfaction due to high demands of the job and the strategic value of their motivation and psychological wellbeing to enhance firm performance and competitiveness. Therefore, the current study is important in filling the void in the literature by focusing on shipping organizations that seems to expose their employees to high levels of emotional and work-related stresses leading to decreased JS which in turn can affect absenteeism, performance, productivity and turnover [23][24][25].

\section{Theoretical Background and Hypotheses}

Organizational justice is a concept basically used to describe subjective fairness perceptions in the work environment. As Adams put forward years ago in his wellknown equity theory, employees compare their input (contributions) and output (rewards) with those of relevant workers and conclude if they are being treated fairly or not [26]. For instance, when an individual explores that a co-worker with the same seniority and experience has a higher status than himself/herself, s/he is likely to perceive the situation as unfair. Besides, social exchange theory which assumes sources are exchanged via a process of repayment is a breeding ground for perceived justice [27] whereby one party tends to reciprocate the good or bad actions of another party[28]. Accordingly, 
the positive judgement of employees regarding the supervisor or organization may probably result in a sense of obligation to reciprocate positively[29]. So, it seems logical to expect that positive justice perception of seafarers is likely to turn into desired responses such as motivation, satisfaction and commitment.

Recent progress and perspectives in this area describe three sorts of organizational justice including procedural, interactional and distributive [30]. Building on the equity theory [26], distributive justice placed emphasis on the equitableness of the outcomes (e.g., pay, rewards, promotions) while procedural justice on the fairness of the process like policies and procedures [30][31]. On the other hand, interactional justice focuses the degree to which employees are treated with dignity, politeness, gentleness and respect by supervisors in the application of related operations [32]. Researches on organizational justice have proved that fairness perceptions at work may affect individuals' critical work manners and behaviours like organizational commitment [33][34], organizational citizenship behaviour [35][36][37] performance [30] [38] innovative behaviour [39][40] and turnover intentions [41][42].

Most of the previous studies conclude that three dimensions of justice perception act in a holistic way but participants felt justice in different ways. For instance, Robbins [43] argued that in high perceptions of procedural justice, employees look up positively to their supervisors, even if they are dissatisfied with their salaries, job opportunities, and other personal variables. Some individuals may feel justice in the way the outcomes were distributed while others feel it in management support. These different perceptions with regard to dimensions of organizational justice may be explained by Maslow's wellknown hierarchy of needs in which needs and expectations are categorized. When employees' contributions are rewarded in terms of their own needs and expectations, their perception of justice would increase as well. Accordingly, perhaps the conditions of specialty settings differentiate according to what employees value most and these incoherences (between perceived importance and perceived fulfilment) significantly influence seafarers POJ. Thus, the following is proposed;

Hypothesis 1: There are significant differences among seafarers' perception mean scores with regard to dimensions of organizational justice.

There is also a considerable amount of research indicating that there exists a significant correlation between POJ and JS [2][44][45][46][47][48]. Job satisfaction is explained as a positive emotional response of an employee at the workplace resulting from the assessment of five dimensions such as satisfaction with work, pay, promotion opportunities, supervision, and co-worker [49]. Karimi et al. [50] referred to JS as employees' feeling of job or the emotional reaction to the work environment. Such a perception depended on the gap of employees acquired rewards and the expected deserved rewards in the specific work environment. The smaller gap would present higher satisfaction, while the larger gap would result in lower satisfaction. In other words, JS relied on individuals assessing the objective environment and various factors and comparing past experiences with reference to other groups [51]. Organizational scholars recognize the importance of investigating the antecedents of JS because it has been discovered not only to reduce absenteeism and turnover intentions [52][53][54][55] but also increase employees' commitment [53][55] [56][57].

High turnover rates present a number of risks to the shipping industry and thus place great importance on seafarers JS 
because it is directly related to the retention in the seafaring profession. Accordingly, $\mathrm{Li}$ and colleagues investigated the main factors that contribute to JS and found that promotion is the key factor in the JS of the Chinese seafarers [58]. In another study, [59] participants stated that income as the only source of pleasure related to the job and the primary reason for being in this job. In addition, they also emphasized financial stability and security as a source of satisfaction. Studies have also shown that organizational support, job demands, and team cohesion are among the important factors related to JS of seafarers [60], [61]. Factors including salary, promotion opportunities, fringe benefits, supervision, co-workers, job conditions, the nature of the work, organizational support and communication have been frequently linked to satisfaction and thus inconsistent or unfair treatment of these factors may lead to low JS [15][58][60][61][62][63]. Consequently, employees would perceive the organization as fair if the comparison of these elements results in a positive way which leads to the development of the following hypothesis to be tested;

\section{Hypothesis 2: Seafarers' POJ positively affects their JS.}

Reviewing past studies also reveals that demographic characteristics such as age marital status, gender, job position, education, job satisfaction, organizational tenure may influence the perceptions of individuals. Different needs and expectations of different demographic and personality groups can affect the feeling of organizational justice. However, it is also important to note that all members of the same demographic group do not necessarily share similar experiences and hence have the same justice perceptions [64]. For instance, in some studies, gender differences found to moderate the POJ and JS [65]) whereas some others found no significant differences [66]. Organizational tenure is another demographic variable that is frequently linked to both justice and satisfaction. Relatedly, Pignata \& colleagues [67] found that academic staff's tenure predicted perceived justice which was the strongest determinant of academic staff's JS. This result is also supported by two studies of Bidarian \& Jafari [68] which point that there is poor but positive linkage between perceived justice and the length of work experience. Accordingly, it is proposed;

Hypothesis 3: Seafarers' sea service period moderates the relationship between POJ and JS.

Consequently, past studies revealed significant relationships between the three facets of justice and JS. However, the topic is generally investigated by using samples drawn from the employees of west organizations with similar occupations. The lack of studies investigating the relationship between POJ and JS on a particular working environment of seafarers increase the importance of this study. Consequently, the present study intends to enhance the literature by examining the following research model in Figure 1 with data drawn from a probability sample of seafarer's from Turkey.

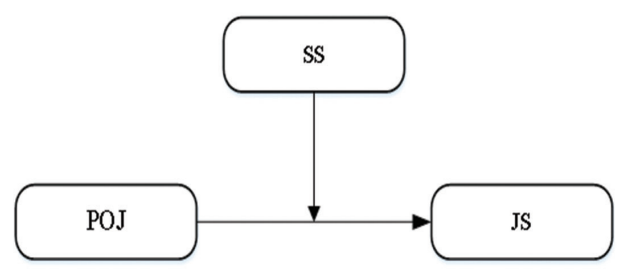

Figure 1. Research Model

\section{Method}

This study was conducted to measure the organizational justice perceptions of seafarers and to examine the causal relationships between their POJ and JS. The data were collected using face-to-face survey method, and analyzed by SPSS 22 and AMOS 22 statistical package programs 
using descriptive statistics, skewness and kurtosis coefficients, convergent and discriminant validity in confirmatory factor analysis for validity analysis, Cronbach's alpha and composite reliability coefficients in reliability analysis. Correlation analysis, dependent-samples one-way analysis of variance (ANOVA), path analysis and structural equation modelling were used to test research hypotheses.

\subsection{Sample}

The sample consists of Turkish seafarers working on merchant ships. The data were collected using convenience sampling method and face-to-face survey from seafarers working on ships including ferries, passenger boats and sea buses used for passenger transportation in the Marmara Region.

\subsection{Data Collection Tools}

The survey form consists of two sections. The first section includes questions about the seafarers' demographic features such as age, gender, education and working time at sea, and the second section includes two scales to measured the research variables including POJ and JS. Five-point Likert scale (scoring between 1= strongly disagree and 5= strongly agree) is used to rate the perceptions of seafarers. POJ scale configured by Neiehoff \& Moorman [69] and adapted to Turkish by Ylddırım [70] covers 20-items relating to three facets of justice; distributive justice perception (DJP) (5 items), procedural justice perception (PJP) (6 items) and interactional justice perception (IJP) ( 9 items). Some of the scale items are as follows: "I think the arrangements on my working hours onboard are fair", "Seafarers' opinions are asked before any decision about works on board", and "My supervisor onboard explains every decision about my job very clearly and in details". According to the results of the exploratory factor analysis
(EFA) applied using varimax rotation and principal components analysis techniques to determine the consistency of POJ scale, it was revealed that the scale had a three-dimensional structure (PJP, DJP and IJP) with eigenvalues greater than 1 as in previous studies (KMO $=0.954$; $\chi \quad 2=4466.375 ; \mathrm{df}=190 ; \mathrm{p}<0.001$; factor loadings ranging between 0.565-0.878; total explained variance: $64.7 \%$ ). Table 1 presents the goodness of fit indices of the first and second-order confirmatory factor analysis (CFA) performed to determine the structural validity of the scale. Accordingly, both the first $(\chi 2 / \mathrm{df}: 2.477$; GFI: 0.894; CFI: 0.945; TLI:0.936; RMSEA:0.066) and second ( $\chi 2 / \mathrm{df}$ : 2.410; GFI: 0.897; CFI: 0.948; TLI: 0.939; RMSEA: 0.065 ) order fit indices were within acceptable values [71],[72]. In addition, the average variance extracted (AVE) and composite reliability (CR) values were calculated to determine the convergent and discriminant validity in DFA, and results are given in Table 2. Accordingly, the factor loadings of observed variables varied between 0.577 and 0.857 , and the t-test values were statistically significant ( $p<0.001)$. The standardized $\beta$ coefficients of observed variables were higher than the threshold value of 0.50 , and the AVE values were higher than the critical value of 0.50 . Furthermore, the $C R$ values were higher than the critical value of 0.70 and AVE values suggested a convergent validity between the dimensions of the measurement model. However, due to correlation coefficients between the dimensions of the measurement model lower than the square roots of AVE values, the discriminant validity was also achieved [73]. In the reliability analysis, the Cronbach's Alpha (CA) coefficients ranged between 0.842-0.928 and the CR coefficients between 0.888-0.960. Accordingly, the organizational justice perception scale is valid and reliable [72][73].

JS scale developed by Chen et al. [74] 
Table 1. Confirmatory Factor Analysis Goodness of Fit Indices

\begin{tabular}{|l|c|c|c|c|c|c|c|}
\hline Scales & $\chi \mathbf{2}$ & sd & $\chi \mathbf{2} / \mathbf{s d}$ & GFI & CFI & TLI & RMSEA \\
\hline First Order POJ & 406.190 & 164 & 2.477 & .894 & .945 & .936 & .066 \\
\hline Second Order POJ & 392.824 & 163 & 2.410 & .897 & .948 & .939 & .065 \\
\hline JS & 10.138 & 4 & 2.535 & .988 & .957 & .983 & .068 \\
\hline
\end{tabular}

Table 2. Confirmatory Factor Analysis Results

\begin{tabular}{|c|c|c|c|c|c|c|}
\hline Factors & $\begin{array}{l}\text { Observed } \\
\text { Variables }\end{array}$ & Standardized $\beta$ & t Values & AVE & CR & CA \\
\hline \multirow{6}{*}{ PJP } & PJP1 & .577 & $7.701^{* * *}$ & \multirow{6}{*}{.522} & \multirow{6}{*}{.866} & \multirow{6}{*}{.842} \\
\hline & PJP2 & .766 & $11.128^{* * *}$ & & & \\
\hline & PJP3 & .829 & $11.716^{* * *}$ & & & \\
\hline & PJP4 & .803 & $11.482^{* * *}$ & & & \\
\hline & PJP5 & .717 & $10.635^{* * *}$ & & & \\
\hline & PJP6 & .605 & - & & & \\
\hline \multirow{5}{*}{ DJP } & DJP7 & .746 & $12.689^{* * *}$ & \multirow{5}{*}{.587} & \multirow{5}{*}{.876} & \multirow{5}{*}{.873} \\
\hline & DJP8 & .786 & $13.332^{* * *}$ & & & \\
\hline & DJP9 & .734 & $12.499^{* * *}$ & & & \\
\hline & DJP10 & .857 & $14.407^{* * *}$ & & & \\
\hline & DJP11 & .698 & - & & & \\
\hline \multirow{9}{*}{ IJP } & IJP12 & .727 & $13.416^{* * *}$ & \multirow{9}{*}{.582} & \multirow{9}{*}{.926} & \multirow{9}{*}{.928} \\
\hline & IJP13 & .782 & $14.552^{* * *}$ & & & \\
\hline & IJP14 & .758 & $14.072^{* * *}$ & & & \\
\hline & IJP15 & .710 & $14.861^{* * *}$ & & & \\
\hline & IJP16 & .830 & $15.563^{* * *}$ & & & \\
\hline & IJP17 & .838 & $15.736^{* * *}$ & & & \\
\hline & IJP18 & .727 & $13.423^{* * *}$ & & & \\
\hline & IJP19 & .739 & $13.665^{* * *}$ & & & \\
\hline & IJP20 & .746 & - & & & \\
\hline \multirow{5}{*}{ JS } & JS1 & .730 & $9.282^{* * *}$ & \multirow{5}{*}{.519} & \multirow{5}{*}{.841} & \multirow{5}{*}{.728} \\
\hline & JS2 & .842 & $9.735^{* * *}$ & & & \\
\hline & JS3 & .562 & $7.634^{* * *}$ & & & \\
\hline & JS4 & .724 & $9.222^{* * *}$ & & & \\
\hline & JS5 & .715 & - & & & \\
\hline
\end{tabular}

$* * * \mathrm{p}<0.001$

and adopted to Turkish by Turunç and Çelik [75] is used to rate JS levels of seafarers. Some example items are as follows: "I am satisfied with my job onboard" and "I feel like the day will never end when I do my work onboard" (reverse coded). According to the EFA results applied using varimax rotation and principal analysis to determine the consistency of the JS scale, it was revealed that the scale has a one-dimensional 
structure with an eigenvalue greater than 1 as in previous studies $(\mathrm{KMO}=0.731 ; \chi$ 2 = 368.170; $\mathrm{df}=10$-factor loads ranging from $\mathrm{p}<0.001 ; 0.589-0.896$; total explained variance: $57.2 \%$ ). Table 1 presents the DFA goodness of fit indices calculated to determine the structural validity of the scale. Accordingly, the fit indices of this single-factor JS scale ( $\chi 2 / \mathrm{df}$ : 2.535; GFI: 0.988; CFI: 0.957; TLI: 0.983; RMSEA: 0.068) were within acceptable values [71],[72]. In addition, the average variance extracted (AVE) and composite reliability (CR) values were calculated to assess the scale's convergent and discriminant validity in DFA, and the results are given in Table 2. Accordingly, the factor loadings of observed variables varied between 0.524 and 0.842 , and the t-test values were statistically significant $(\mathrm{p}<0.001)$. The standardized $\beta$ coefficients of observed variables were higher than the threshold value of 0.50 , and the AVE values were higher than the crucial value of 0.50 . Furthermore, the higher CR values than the critical value of 0.70 and the AVE values suggest a convergent validity of the measurement model. Cronbach's Alpha
(CA) and CR coefficients of the scale were found as 0.728 and 0.815 respectively which indicates JS scale is valid and reliable [72][73].

Before testing the research hypotheses, the skewness and kurtosis coefficients of the observed variables were examined to determine whether the data had a normal distribution. As the coefficients ranged between -1.5 and +1.5 , the data were considered to have a normal distribution.

\section{Results}

\subsection{Demographic Characteristics of Participants}

Table 3 presents the seafarers' demographic characteristics. Accordingly, $94.3 \%(n=316)$ of them are male, $30.4 \%$ $(n=102)$ are $31-40$ years old, $49.2 \%$ $(n=170)$ are high school graduates, $25.4 \%$ $(n=85)$ have work experience between 4-7 years, and $60.3 \%(n=202)$ are deck crew.

\subsection{Hypothesis Testing}

Table 4 presents the means, standard deviations and correlation coefficients of the research variables.

Table 3. Demographic Characteristics of Participants

\begin{tabular}{|c|c|c|c|c|c|c|c|}
\hline Variables & Groups & $\mathbf{n}$ & $\%$ & Variables & Groups & $\mathbf{n}$ & $\%$ \\
\hline \multirow{3}{*}{ Gender } & Female & 19 & 5.7 & \multirow{6}{*}{$\begin{array}{c}\text { Work } \\
\text { Experience }\end{array}$} & $\begin{array}{l}3 \text { years and } \\
\text { under }\end{array}$ & 71 & 21.2 \\
\hline & Male & 316 & 94.3 & & 4-7 years & 85 & 25.4 \\
\hline & Total & 335 & 100.0 & & 8-11 year & 64 & 19.1 \\
\hline \multirow{5}{*}{ Age } & $20-25$ & 57 & 17.0 & & $12-15$ years & 36 & 10.7 \\
\hline & $26-30$ & 68 & 20.3 & & 16 and over & 79 & 23.6 \\
\hline & $31-40$ & 102 & 30.4 & & Total & 335 & 100.0 \\
\hline & $41-50$ & 77 & 23.0 & \multirow{6}{*}{ Department } & Deck & 202 & 60.3 \\
\hline & 51 and over & 31 & 9.3 & & Engine & 101 & 30.1 \\
\hline \multirow{4}{*}{$\begin{array}{l}\text { Education } \\
\text { status }\end{array}$} & Primary & 55 & 16.4 & & Galley & 32 & 9.6 \\
\hline & High school & 170 & 49.2 & & Total & 335 & 100.0 \\
\hline & University & 110 & 32.8 & & & & \\
\hline & Total & 335 & 100.0 & & & & \\
\hline
\end{tabular}


Table 4. Means, Standard Deviations and Correlation Coefficients

\begin{tabular}{|l|l|l|l|l|l|l|}
\hline Values & Means & SS & $\mathbf{1}$ & $\mathbf{2}$ & $\mathbf{3}$ & $\mathbf{4}$ \\
\hline 1. PJP & 3.688 & .785 & 1 & & & \\
\hline 2. DJP & 3.628 & .845 & $.794^{* *}$ & 1 & & \\
\hline 3. IJP & 3.936 & .735 & $.734^{* *}$ & $.716^{* *}$ & 1 & \\
\hline 4. POJ & 3.751 & .719 & $.924^{* *}$ & $.914^{* *}$ & $.888^{* *}$ & 1 \\
\hline 5. JS & 3.796 & .636 & $.373^{* *}$ & $.363^{* *}$ & $.415^{* *}$ & $.419^{* *}$ \\
\hline
\end{tabular}

${ }^{* *} \mathrm{p}<0,01$

There is a moderate and statistically significant relationship among seafarers' mean scores of JS, POJ, and three dimensions of justice. Mean scores of three dimensions of justice point a difference among justice perceptions of seafarers. The dependent samples' one-way analysis of variance was performed to reveal whether these differences were statistically significant or not. Firstly, Levene's test, a prerequisite of one-way analysis of variance, was conducted to check homogeneity between the groups (Table 5).

Table 5. Levene's Test

\begin{tabular}{|c|c|c|c|c|}
\hline Values & $\begin{array}{c}\text { Levene's } \\
\text { Test }\end{array}$ & $\mathbf{d f 1}$ & $\mathbf{d f 2}$ & $\mathbf{p}$ \\
\hline 1. PJP & 1.599 & 4 & 330 & .174 \\
\hline 2. DJP & 1.395 & 4 & 330 & .235 \\
\hline 3. IJP & 2.064 & 4 & 330 & .085 \\
\hline
\end{tabular}

Accordingly, the dimensions of organizational justice were homogeneous $[\alpha(0.05)<p]$, and thus the prerequisite of variance analysis for these variables was met. After the dependent samples' one-way analysis of variance confirmed that the model was statistically significant $[\alpha(0.01)>p$; F:66.653], binary comparisons were applied to determine whether the difference between groups was significant (Table 6).

Consequently, the difference between seafarers' mean scores on organizational justice perception subscales was statistically significant. Therefore, Hypothesis 1 was accepted. The goodness of fit indices $(\chi 2)$ df:2.239; GFI:0.876; CFI:0.932; TLI:0.924; RMSEA:0.061) regarding the structural

Table 6. Variance Analysis Binary Comparison

\begin{tabular}{|ll|l|l|l|}
\hline $\begin{array}{l}\text { (I) Factor1 } \\
\text { (J) Factor 1 }\end{array}$ & $\begin{array}{l}\text { Average } \\
\text { Difference (I-J) }\end{array}$ & Std. Dev. & p \\
\hline PJP & DJP & $.059^{*}$ & .029 & .040 \\
& IJP & $-.248^{*}$ & .030 & .000 \\
\hline DJP & PJP & $-.059^{*}$ & .029 & .040 \\
& IJP & $-.308^{*}$ & .033 & .000 \\
\hline IJP & PJP & $.248^{*}$ & .030 & .000 \\
& DJP & $.308^{*}$ & .033 & .000 \\
\hline
\end{tabular}

equation modelling in Figure 2, which was implemented to reveal the effect of POJ on JS were within acceptable values [71],[72]. The path analysis revealed that POJ had a significant positive effect on JS (std. $\beta$ : 0.507; t: 6.518; $\left.\mathrm{p}<0.001 ; \mathrm{R}^{2}: 25.7\right)$ and explained around $26 \%$ of the variance of JS. Therefore, Hypothesis 2 was accepted, too.

To discover the moderating role of seafarers' service (SS) period at sea in the relationship between POJ and JS, the PROCESS macro plugin in SPSS 22 program was used[76]. The results of the moderating role analysis with the Bootstrap 5000 sample are shown in Table 7.

Table 7. Moderating Effect Analysis

\begin{tabular}{|l|l|l|l|l|l|}
\hline & \multirow{2}{*}{ B } & SE & \multicolumn{1}{|}{ t } & \multicolumn{2}{c|}{ 95\% CI } \\
& & & \multicolumn{1}{|c|}{ UL } \\
\hline Constant & 3.790 & 0.031 & 120.685 & 3.729 & 3.852 \\
\hline POJ & $0.411^{* * *}$ & 0.045 & 8.994 & 0.321 & 0.501 \\
\hline SS & 0.007 & 0.021 & 0.370 & -0.033 & 0.049 \\
\hline POJ*SS & $-0.073^{*}$ & 0.029 & -0.249 & -0.131 & -0.015 \\
\hline Model Summary & \multicolumn{5}{|l}{$\mathrm{R}^{2}=0.196 ; \mathrm{F}=27.030 ; \mathrm{p}<0.01$} \\
\hline Change in R-sq. & \multicolumn{5}{|l}{$\Delta \mathrm{R}^{2}=0.015 ; \mathrm{F}=6.246 ; \mathrm{p}<0.05$} \\
\hline
\end{tabular}

$*_{\mathrm{p}<0.05 ;{ }^{* * *} \mathrm{p}<0.01}$ 


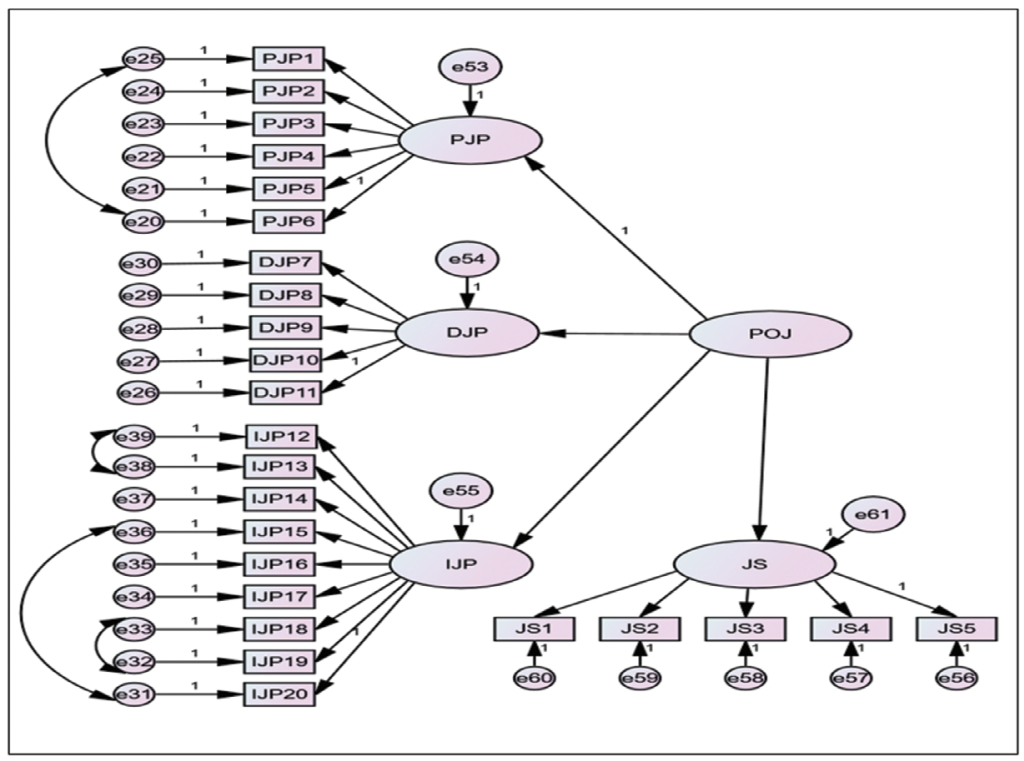

Figure 2. Structural Equation Modeling

The results presented in Table 7 points that moderating effect of SS period is significant $\left(R^{2}=0.196 ; F=27.030 ; p<0,01\right)$ and the effect of the interaction term (POJ * SS) on JS is also significant $(\mathrm{B}=0.073 ; \mathrm{t}=-0.249 ; \mathrm{p}<0.05$; $-0.113<$ LL 95\% CI <-0.015; $\Delta \mathrm{R}^{2}=0.015$ ).
Therefore, Hypothesis 3 was accepted. Slope test was performed to determine whether POJ differs from zero from the average of working time at sea, a standard deviation from the average of working time [77], and the results are presented in Figure 3.

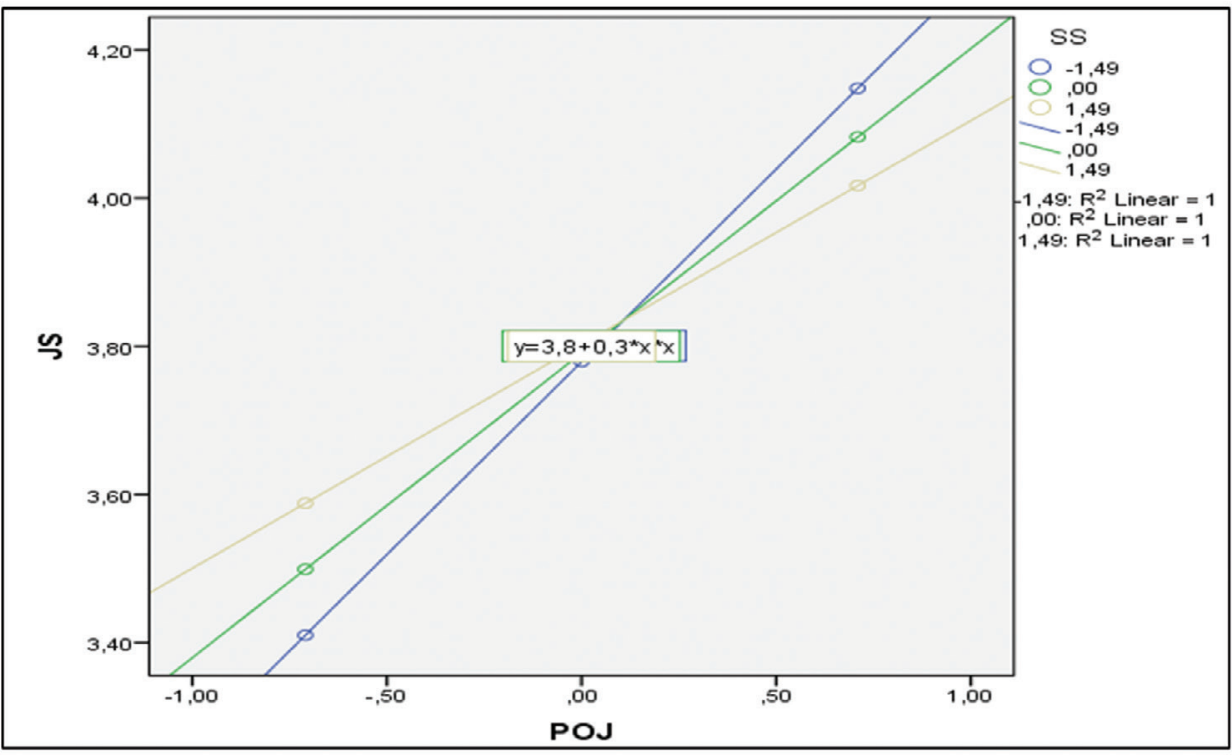

Figure 3. Slope Graph of Organizational Justice Perception and Sea Service Interaction 
It is understood from Figure 3 that the relationship between POJ and JS is more powerful for seafarers whose length of sea service is shorter.

\section{Discussion and Conclusions}

The current study tests the effect of justice perception between seafarers on JS. The results show that the difference among seafarers' mean scores on organizational justice perception subscales is statistically significant. Accordingly, the level of distributive justice perception of seafarers (X:3.628) is lower than perceived procedural (X:3.688) and interactional justice (X:3.936). This result provides support for the organizational justice literature that suggests individuals from different contextual circumstances focus on a different criterion to rate justice [78],[79],[80]. Like Ambrose \& Schmin [80] claim employees view justice dimensions differently and are apt to perceive one higher that serve the needs of the individual. Therefore, the low level of distributive justice might be due to the perception that salaries, promotional opportunities and organizational resources are generally insufficient when hidden costs involved for working onboard a ship is considered. This finding of the study suggests that seafarers perceive equity in the amount of compensation they receive and thus shipping companies need to find a delicate balance between seafarers' contributions and compensation.

The study also reveals that the level of perceived interactional justice (X:3.936) is greater than the other two dimensions of organizational justice. The attributes of the maritime companies may play a considerable role in seafarers' justice judgement. Shipping firms generally operate in a closed business environment where power and decision making is centralized, and communication channels follow a strict hierarchy. Besides, isolation is an innate characteristic of the prevalent system onboard which may lead to a tendency to reduce interpersonal relationships. These characteristics of the working environment are well known among sea labour and thus may have created a negative bias and expectation towards interactional justice which seems to be the reason for rating the perceived interactional justice higher. In other words, unlike common practice, in the application of related operations, the ship managers within the scope of the current research seem to treat seafarers with dignity, politeness, gentleness and respect. Thus, seafarers who do not have many expectations in this regard may have felt interactional justice more than the other dimensions of justice.

So far, scholars have pointed out the link between POJ and JS but testing the similar link within the maritime context is neglected. Drawing on this idea, perhaps the most important benefaction of the current study is that it provides empirical support for the interaction between justice perceptions of seafarers and their satisfaction. The path analysis which was performed using the structural equation modelling has revealed that as predicted justice perception of seafarers positively affects their JS level (std. $\beta: 0.507 ; \mathrm{t}: 6.518$; $\mathrm{p}<0.001$ ) and explained around $26 \%$ of the variance in $\mathrm{JS}\left(\mathrm{R}^{2}: 25.7\right)$. This finding of the study is consistent with previous studies that found POJ to be positively related to JS [81], [82]. Although such connection is intensely verified among different occupations in the literature, this study extends prior researches by investigating the link between organizational justice and satisfaction for the first time in the shipping industry.

Furthermore, the results confirm that the length of seafarers' sea service has a moderating role $(\mathrm{B}=0.073 ; \mathrm{t}=-0.249 ; \mathrm{p}$ $<0.05$; $-0.131<$ LL 95\% CI <-0.015) between POJ and JS. Short-tenured seafarers have 
reported more positive views of fairness at work which moderates the relationship between POJ and JS. A possible explanation for this result is that seafarers entering a company may be more responsive to justice in the work environment which in turn influence their satisfaction levels. Maybe, it is more important for younger employees to have a job and that's why seafarers who have less experience with the organization are more likely to tolerate the shipping organization for making a justice violation. On the other hand, seafarers who have contributed to the organization with their experience and knowledge for years may think that they are not getting enough compensation for this long-term relationship.

The findings of the study should be judged given some constraints. For instance, there is some evidence in the literature that the different dimensions of organizational justice can have different effects on individuals' behaviours. According to Cohen-Charash \& Spector's meta-analysis [64], distributive justice is the dominant factor that impacts satisfaction whereas Colquitt and colleagues [83] metaanalysis concluded procedural justice as the more effective determinant. Future studies that investigate which dimension of organizational justice has a higher impact on seafarers' job satisfaction would contribute to the literature. On the other hand, there is also some evidence in the literature that the amount of organizational justice demanded by staff from their organizations may be influenced by their national culture which in turn would affect their level of satisfaction. The individuals from high power distance culture may demand less interactional justice compared to those with low power distance since it basically requires the cooperation and communication between employees and the administrators. From this point of view, further studies can be performed to investigate the effect of culture on the relationship between research variables. Second, the generalization of sampling is arguable because the survey was realized in a particular context. Therefore, the moderating effect of the length of seafarers' service at sea on the relationship between POJ and JS may be deepened with data obtained from different industries and the comparison of different industries will deepen the understanding of the process.

\section{References}

[1] Dailey, R. C. , \& Kirk, D. J. (1992). Distributive and Procedural Justice as Antecedents of Job Dissatisfaction and Intent to Turnover. Human Relations, 45(3), 305-317.

[2] McFarlin, D. B., \& Sweeney, P. D. (1992). Distributive and Procedural Justice as Predictors of Satisfaction with Personnel and Organizational Outcomes. Academy of Management Journal, 35(3), 626-637.

[3] Cropanzano, R. , \& Ambrose, M. L. (2001). Procedural and Distributive Justice are More Similar Than You Think: A Monistic Perspective and a Research Agenda. In J. Greenberg \& R. Cropanzano (Ed.), Advances in Organizational Justice (pp. 119-151). Lexington: New Lexington Press.

[4] Oldenburg, M., Jensen, H. J., Latza, U., \& Baur, X. (2009). Seafaring Stressors Aboard Merchant and Passenger Ships. International Journal of Public Health, 54(2), 96-105.

[5] Oldenburg, M., Baur, X., \& Schlaich, C. (2010). Occupational Risks and Challenges of Seafaring. Journal of Occupational Health, 52(5), 249256.

[6] Carotenuto, A., Molino, I., Fasanaro, A. M., \& Amenta, F. (2012). Psychological Stress in Seafarers: A review. International Maritime Health, 63(4), 188-194. 
[7] Hystad, S.W., Saus E.R., Sætrevik B., \& Eid J. (2013). Fatigue in Seafarers Working in the Offshore Oil and Gas Re-Supply Industry: Effects of Safety Climate, Psychosocial Work Environment and Shift Arrangement. Internatonal Maritime Health, 64(2), 72-79.

[8] Comperatore, C. A., Rivera, P. K., \& Kingsley, L. (2005). Enduring The Shipboard Stressor Complex: A Systems Approach. Aviation, Space and Environmental Medicine, 76(6 Suppl), B108-B118.

[9] Allen, P., Wadsworth, E., \& Smith, A. (2008). Seafarers' Fatigue: A Review of the Recent Literature. International Maritime Health, 59(1-4), 81-92.

[10] Cahoon, S., \& Haugstetter, H. (2008). Shipping, Shortages and Generation Y. 8th International Conference on Maritime Training, Communication and Technology (MARTECH) (pp. 1-9). Singapore.

[11] Bhattacharya, D. (2015), Nonparametric Welfare Analysis for Discrete Choice. Econometrica, 83(2), 617-649. https://doi.org/10.3982/ ECTA12574.

[12] Ruggunan, S., \& Kanengoni, H. (2017). Pursuing a Career at Sea: An Empirical Profile of South African Cadets and Implications for Career Awareness. Maritime Policy \& Management, 44(3), 289-303.

[13] Zaar, S., \& Hammarstedt, K. (2012). Promotion Campaigns in the Maritime Sector and the Attitude of Young People towards a Career at Sea (MSc Thesis). Chalmers University of Technology.

[14] Fei, J., \& Lu, J. (2014). Analysis of Students' Perceptions of Seafaring Career in China Based on Artificial Neural Network and Genetic Programming. Maritime Policy \& Management, 42(2), 111-126.
[15] Yuen, K. F., Loh, H. S., Zhou, Q., \& Wong, Y. D. (2018). Determinants of Job Satisfaction and Performance of Seafarers. Transportation Research Part A: Policy and Practice, 110, 1-12.

[16] Efraty, D., \& Sirgy, M. J. (1990). The Effects of Quality Of Working Life (QWL) on Employee Behavioral Responses. Social Indicators Research, 22(1), 31-47.

[17] King, A. S., \& Ehrhard, B. J. (1997). Empowerment the Workplace: A Comminment Cohosion Exercise. Empowerment in Organizations, 5(3), $139-150$.

[18] Allan, P., \& Loseby, P. H. (1993). No-Layoff Policies and Corporate Financial Performance. SAM Advanced Management Journal, 58(1), 44-49.

[19] Danna, K., \& Griffin, R. W. (1999). Health and Well-Being in the Workplace: A Review and Synthesis of the Literature. Journal of Management, 25(3), 357-384.

[20] Chan, K. W., \& Wyatt, T. A. (2007). Quality of Work Life: A Study of Employees in Shanghai, China. Asia Pacific Business Review, 13(4), 501-517.

[21] Kanten, S., \& Sadullah, O. (2012). An Empirical Research On Relationship Quality Of Work Life And Work Engagement. Procedia Social and Behavioral Sciences, 62, 360 - 366.

[22] De Jong, B. A., Kroon, D. P., \& Schilke, O. (2015). The future of organizational trust research: a content-analytic synthesis of scholarly recommendations and review of recent developments. In Rockenbach, B., van Lange, P., \& Yamagishi, T. (Ed.), Trust in Social Dilemmas (pp. 173-194). New York: Oxford University Press. 
[23] Lyubomirsky, S., King, L., \& Diener, E. (2005). The Benefits of Frequent Positive Affect: Does Happiness Lead to Success?. Psychological Bulletin, 131(6), 803-855.

[24] Wang, Y-D. \& Yang, C. (2016). How Appealing are Monetary Rewards in the Workplace? A Study of Ethical Leadership, Love of Money, Happiness, and Turnover Intention. Social Indicators Research, 129(3), 1277-1290.

[25] Di Castro, V.C., Hernandes, J. C, Mendonca, M.E., \& Porto, C. C. (2018). Life Satisfaction and Positive and Negative Feelings of Workers: A Systematic Review Protocol. Systematic Reviews, 7(1), 1-6.

[26] Adams, J. S. (1965). Inequity in Social Exchange. Advances in Experimental Social Psychology, 2, 267-299.

[27] Cropanzano, R. , \& Mitchell, M. S. (2005). Social Exchange Theory: An Interdisciplinary Review. Journal of Management, 31(6), 874-900.

[28] Gouldner, A. (1960). The Norm of Reciprocity: A Preliminary Statement. American Sociological Review, 25(2), 161-178.

[29] Wayne, S. J., Shore, L. M., Bommer, W. H., \& Tetrick, L. E. (2002). The Role of Fair Treatment and Rewards in Perceptions of Organizational Support and Leader-Member Exchange. Journal of Applied Psychology, 87(3), 590 -598.

[30] Judge, T. A., \& Colquitt, J. A. (2004). Organizational Justice and Stress: The Mediating Role of WorkFamily Conflict. Journal of Applied Psychology, 89(3), 395-404.

[31] Thibaut, J. W., \& Walker, L. (1975). Procedural Justice: A Psychological Analysis. (Hillsdale, N.J., Ed.): Lawrence Erlbaum Assoc.
[32] Bies, R. J. (2001). Interactional (In) justice: The Sacred and the Profane. In J. Greenberg \& R. Cropanzano (Ed.), Advances in Organizational Justice (pp. 89-118). Stanford, CA: Stanford University Press.

[33] Kwong, J.Y. \& Leung, K. (2002). A Moderator of the Interaction Effect of Procedural Justice and Outcome Favourability: Importance of the Relationship. Organizational Behavior and Human Decision Processes, 87(2), 278-300.

[34] Mathieu, J.E. \& Zajac, D.M. (1990). A Review and Meta-analysis of the Antecedents, Correlates and Consequences of Organizational Commitment. Psychological Bulletin, 108(2), 171-194.

[35] Niehoff, B. P., \& Moorman, R. H. (1993). Justice as a Mediator of the Relationships Between Methods of Monitoring and Organizational Citizenship Behavior. Academy of Management Journal, 36(3), 527556.

[36] Skarlicki, D. P., \& Latham, G. P. (1997). Leadership Training in Organizational Justice to Increase Citizenship Behavior within a Labor Union: A Replication. Personnel Psychology, 50(3), 617-633.

[37] Moorman, R.H., Blakely, G.L., \& Niehoff, B.P. (1998). Does Perceived Organizational Support Mediate the Relationship Between Procedural Justice and Organizational Citizenship Behavior?. Academy of Management Journal, 41(3), 351357.

[38] Wang, X., Liao, J., Xia, D. \& Chang, T. (2010). The Impact of Organizational Justice on Work Performance: Mediating Effects of Organizational Commitment and Leader-Member Exchange. International Journal of Manpower, 31(6), 660-677. 
[39] Moon, H. , Kamdar, D., Mayer, D. M. , \& Takeuchi, R. (2008). Me or We? The Role of Personality and Justice as Other-Centered Antecedents to Innovative Citizenship Behaviors Within Organizations. Journal of Applied Psychology, 93(1), 84-101.

[40] Young, L. D. (2012). How to Promote Innovative Behavior at Work? The Role of Justice and Support within Organizations. Journal of Creative Behavior, 46(3), 220-243.

[41] DeConinck, J.B. , \& Stilwell, D.C. (2004). Incorporating Organizational Justice, Role States, Pay Satisfaction and Supervisor Satisfaction in a Model of Turnover Intentions. Journal of Business Research, 57(3), 25-231.

[42] Loi, R., Ngo H. , \& Foley, S. (2006). Linking Employees Justice Perceptions to Organizational Commitment and Intention to Leave: The Mediating Role of Perceived Organizational Support. Journal of Occupational and Organizational Psychology, 79(1), 101-120.

[43] Robbins, S. P. (2007). Fudamentals of Management (6th ed.). Tehran: Nil.

[44] Clay-Warner, J., Reynolds, J., \& Roman P. (2005). Organizational Justice and Job Satisfaction: A Test of Three Competing Models. Social Justice Research, 18(4), 391-409.

[45] Suliman, A., \& Tahir, M. (2007). Links between Justice, Satisfaction and Performance in the Workplace: A Survey in the UAE and Arabic Countries. Journal of Management Development, 26(4): 294-310.

[46] Fatt, C. K., Khin, E.W.K., \& Heng, T. $N$ (2010). The Impact of Organizational Justice on Employee's Job Satisfaction: The Malaysian Companies Perspectives. American Journal of Economics and Business Administration, 2(1), 56-63.
[47] Shah, S. A., Waqas, M. and Saleem, R. (2012). Organizational Justice and Job Satisfaction: The Mediating Role of Trust in Supervisor. International Journal of Human Sciences, 9(1), 672721.

[48] Mete, E. S., \& Sökmen A. , (2019). The Mediating Role of Organizational Commitment in the Organizational Justice's Effect on Job Satisfaction and Turnover Intention: A Research on Academic Staff. Gazi Íktisat ve İşletme Dergisi, 5(3): 193-205.

[49] Smith, P. C., Kendall, L. M. , \& Hulin, C. L. (1969). The Measurement of Satisfaction in Work and Retirement: A Strategy for the Study of Attitudes. Chicago: Rand Mcnally.

[50] Karimi, L., Leggat, S. G., Donohue, L., Farrell, G., \& Couper, G. E. (2013). Emotional Rescue: The Role of Emotional Intelligence and Emotional Labour on Well-Being and Job-Stress Among Community Nurses. Journal of Advanced Nursing, 70(1), 176-186.

[51] Yao, C., \& Huang, P. (2018). Effects of Leadership Style on Job Satisfaction and Intention to Stay in Shipping Industry. Journal of Coastal Research, 83, 796-801.

[52] Arnold, H. J., \& Feldman, D. C. (1982). A Multivariate Analysis of the Determinants of Job Turnover. Journal of Applied Psychology, 67(3), 350-360.

[53] Tett, R. P., \& Meyer, J. P. (1993). Job Satisfaction, Organizational Commitment, Turnover Intention, and Turnover: Path Analyses Based on Meta-Analytic Findings. Personnel Psychology, 46(2), 259-293.

[54] Bakhshi, A., Kumar, K., \& Rani, E. (2009). Organizational Justice Perceptions as Predictor of Job Satisfaction and Organization Commitment. International Journal of Business and Management, 4(9), 145154. 
[55] Johnson, R. E., Chang, C.H. , \& Yang, L.Q. (2010). Commitment and Motivation at Work: The Relevance of Employee Identity and Regulatory Focus. The Academy of Management Review, 35(2), 226245.

[56] Brief, A. P., \& Aldag, R. J. (1980). Antecedents of Organizational Commitment Among Hospital Nurses. Sociology of Work and Occupations, 7(2), 210-221.

[57] Igbaria, M., \& Guimaraes, T. (1993). Antecedents and Consequences of Job Satisfaction among Information Center Employees. Journal of Management Information Systems, 9(4), 145-174.

[58] Li, K. X., Yin, J., Luo, M., \& Wang, J. (2014). Leading factors in job satisfaction of Chinese seafarers. International Journal of Shipping and Transport Logistics, 6(6), 680693.

[59] Slišković, A., \& Penezić, Z. (2015). Descriptive Study of Job Satisfaction and Job Dissatisfaction in a Sample of Croatian Seafarers. International Maritime Health, 66(2), 97-105.

[60] De Silva, R., Stanton, P., \& Stanton, J. (2011). Determinants of Indian Sub-continent Officer-seafarer Retention in the Shipping Industry. Maritime Policy \& Management, 38(6), 633-644.

[61] Nielsen, M. B., Bergheim, K. \& Eid, J. (2013). Relationships Between Work Environment Factors and Workers' Well-Being in the Maritime Industry. International Maritime Health, 64(2), 80-88.

[62] Shields, M. A., \& Ward, M. (2001). Improving Nurse Retention in the National Health Service in England: The Impact of Job Satisfaction on Intentions to Quit. Journal of Health Economics, 20(5), 677-701.
[63] Davey, J. D., Obst, P. L., \& Sheehan, M. C. (2001). Demographic and Workplace Characteristics Which Add to the Prediction of Stress and Job Satisfaction within the Police Workplace. Journal of Police and Criminal Psychology, 16(1), 29-39.

[64] Cohen-Charash, Y.\& Spector, P. E. (2001). The Role of Justice in Organization: A Meta-Analysis. Organizational Behavior and Human Decision Processes, 86(2), 278-321.

[65] Greenberg, J., \& McCarty, C. (1990). The Interpersonal Aspects of Procedural Justice: A New Perspective on Pay Fairness. Labor Law Journal, 41(8), 580-586.

[66] Witt, L. A., \& Nye, L. G. (1992). Gender and the Relationship Between Perceived Fairness of Pay or Promotion and Job Satisfaction. Journal of Applied Psychology, 77(6), 910-917.

[67] Pignata, S., Winefield, A. H. , Provis, C. , \& Boyd, C. M. (2016). A Longitudinal Study of the Predictors of Perceived Procedural Justice in Australian University Staff. Frontiers in Psychology, 7, 1-14.

[68] Bidarian, S., \& Jafari, P. (2012). The Relationship Between Organizational Justice and Organizational Trust. Procedia - Social and Behavioral Sciences, 47, 1622-1626.

[69] Niehoff, B. P., \& Moorman, R. H. (1996). Exploring the Relationships Between Top Management Behaviors and Employee Perceptions of Fairness. International Journal of Public Administration, 19(6), 941-961.

[70] Yıldırım, A., \& Ylldırım, D. (2007). Mobbing in the Workplace by Peers and Managers: Mobbing Experienced by Nurses Working in Healthcare Facilities in Turkey and Its Effect on Nurses. Journal of Clinical Nursing, 16(8), 1444-1453. 
[71] Anderson, J. C., \& Gerbing, D. W. (1998). Structural Equation Modeling in Practice: A Review and Recommended Two-Step Approach. Psychological Bulletin, 103(3), 411423.

[72] Hair, J. F. , Black, W. C. , Babin, B. J. , \& Anderson, R. E. (2010). Multivariate Data Analysis (7th ed.). Upper Saddle River, New Jersey: Prentice Hall.

[73] Fornell, C., \& D. F Larcker (1981). Evaluating Structural Equation Models with Unobservable Variables and Measurement Error. Journal of Marketing Research, 18(1) 39-50.

[74] Chen, G., Kanfer, R. , DeShon, R. P. , Mathieu, J. E. , \& Kozlowski, S. W. J. (2009). The Motivating Potential of Teams: Test and Extension of CrossLevel Model of Motivation in Teams. Organizational Behavior and Human Decision Processes, 110(1), 45-55.

[75] Turunç, Ö. \& Çelik, M. (2012) İş Tatmini-Kişi-Örgüt Uyumu ve Amire Güven Kişi-Örgüt Uyumu İlişkisinde Dağıtım Adaletinin Düzenleyici Rolü. İș, Güç Endüstri Illișkileri ve Insan Kaynakları Dergisi, 14(2), 57 78.

[76] Hayes, A. F. (2017). Introduction to Mediation, Moderation, and Conditional Process Analysis: A Regression-Based Approach. (2nd Edition.) New York: Guilford Publications.

[77] Aiken, L. S. \& West, S.G. (1991). Multiple Regression: Testing and Interpreting Interactions, Newbury Park: Sage Publications, Inc.

[78] Leventhal, G. S. (1980). What Should Be Done With Equity Theory? In K. J. Gergen, M. S. Greenberg, \& R. H. Willis (Eds.), Social Exchange: Advances in Theory and Research (pp. 27-55) . New York: Plenum.
[79] Tyler, T. R. (1996). The Relationship of Outcome and Procedural Fairness: How Does Knowing the Outcome Influence Judgments about the Procedure?. Social Justice Research, 9(4), 311-325.

[80] Ambrose, M. L. \& Schminke, M. (2003). Organization Structure as a Moderator of the Relationship Between Procedural Justice, Interactional Justice, Perceived Organizational Support, and Supervisory Trust. Journal of Applied Psychology, 88(2), 295-305.

[81] McFarlin, D. B., \& Sweeney, P. D. (1992). Distributive and Procedural Justice as Predictors of Satisfaction with Personal and Organizational Outcomes. Academy of Management Journal, 35(3), 626-637.

[82] Bakhshi, A., Kumar, K., \& Rani, E. (2009). Organizational Justice Perceptions as Predictor of Job Satisfaction and Organization Commitment. International Journal of Business and Management, 4(9), 145-154.

[83] Colquitt, J. A., Conlon, D. E. , Wesson, M. J. , Porter, C. O. L. H. , \& Ng, K. Y. (2001). Justice at the Millennium: A Meta-analytic Review of 25 Years of Organizational Justice Research. Journal of Applied Psychology, 86(3), 425-445. 